\title{
Re-examining Industrial Relation Issues for Managing Public Right and Interest in Nigeria
}

\author{
Omoleke Ishaq Isola*, Taiwo Olaiya, Kunle Benson \\ Department of Public Administration, Obafemi Awolowo University, Nigeria
}

Copyright $\bigcirc 2017$ by authors, all rights reserved. Authors agree that this article remains permanently open access under the terms of the Creative Commons Attribution License 4.0 International License

\begin{abstract}
There are several competing issues deducible for the rise in industrial disharmony in government establishments in the recent time. One of such is the dearth of competence and perquisite managerial skill on the part of the authorities for effective management of situations that eventually escalate and lead to industrial breakdown. There is also the school of thought that welfare situation in most government establishments is so much at low ebb that constant industrial challenges have become inevitable. Others argued that the culture of protest against government or allied authorities was inherited during the independence when the nationalists rallied workers behind themselves to drive home their points for self-government. However, there has been scanty attempt to espouse the concrete issues involved in the rules of engagement guiding the legal relationship between labour and managers of public interests. This paper therefore re-examined issues involved in the law and practice of industrial relations in Nigeria with a view to addressing the challenges of incessant breakdown in industrial relations in public offices with emphasis of the right of the two parties involved in industrial relations development in Nigeria.
\end{abstract}

Keywords Industrial Disputes, Industrial Relations, Labour Law, Public Interests, and Conflict Management

\section{Introduction}

Perhaps the most reasonable starting point for this paper is to conceptualise major variables that cut across the paper and these are: labour, management, government and labour Law. For the purpose of this paper the variables are defined as follow:

i. Labour: This implies workforce or the people who work or are available for work.

ii. Management: This refers to a group of the most senior staff of an organization, be it private or public

iii. Government: This connotes a body of political elite who attained governance through party politics.

iv. Administration/Governance refers to administration of human and material resources with a view to achieving organisational goals.

v. The Labour Law: In general, law is an instrument of maintaining social order in a given society. It regulates the rulers and the subjects.

The concept of law can be used in either a general or technical sense. For instance, we can talk of the divine law, law of demand and supply but our main concern here, is in the technical sense.

Even though. nobody including the lawyer, has offered, nobody including the lawyer is offering, nobody including the lawyer will ever be able to offer a definition of law to end all definitions (Professor Okuniga), yet for the purpose of this paper we define law as a body of rules and regulations designed or formulated or rather enacted to guide human conducts or actions which are enforced among the members of a given state and society as earlier mentioned.

Labour law therefore, is that branch of law which' deals with the creation, regulations and formulation of contract of employment between a person and another for the purpose of learning a trade, or working for earning wages whether or not the contract is to be executed independent of control and determines all rights and duties incidental to that relationship under the common law and the statute.

The next challenge is the examination of the nature of the law regulating the relationship among the labour, management and the government in Nigeria; the role the State/Government played and is still playing in shaping the present course of labour and industrial relations development so as to enable it manage the public interest; the purpose for which the state is established.

\section{Background to the Paper}

It is important and necessary to flash back a little bit to Nigerian political development in order to establish the circumstances informing this paper. Nigeria attained 
independence from British Government precisely on $1^{\text {st }}$ October 1960. Not quite six years after independence, that the Military Administration stepped in to administer Nigeria. Given the nature of the military, the use of force, coercion and command theory was the order of the day. In short, the military leadership in Nigeria governance can be described as "the uncommanding commander whose authority cannot be challenged and whose decrees and edicts are final as the Nigeria constitution was suspended. To this end, some unions were banned because they were hostile to the Military Administration. The Unions leaders' position is that the military is an aberration or rather a misnomer and thus its authority must be challenged as radical leaders, they contended.

Finally, the Unions ordinarily believe in democratization of public issues that affect the citizens and also subscribe to symbiotic relationship between the employers and employees. However, it appears this contention of the unions is at variance with the military ideology of command theory and application of force and coercion to govern. These differences gave birth to series of Industrial Strikes and sit down strikes during the military era in Nigeria. This leads us to democratic regime.

The democratic regime is a little bit better as the leaders of the Unions could discuss issues that could lead to industrial disputes with the Minister/Commissioner of Labour and Productivity and perhaps refers the dispute to Arbitration Tribunal. In spite of the legal and ministerial intervention, hardly could Nigerians spend a week without one or two unions on strike and the usual complaints from the Unions concern principally on the welfare of the members of the unions which is a contention between the union and the employer of labour. If it is not Nigeria Medical Association this week, it may be Academic Staff Union of Universities or the Association of Nurses and Midwives or Pharmaceutical Association in the subsequent week or month. Even as at today 11/5/2016, the National Association of Resident Doctors began strike over a better salary and condition of service (NTA News).

Unfortunately, and regrettably these unions ordinarily sound warnings of strike to their employers by giving the legal mandate of two weeks, but Alas!, the Nigerian employers would refuse to take action until the notice expires. This is a bad culture with the Nigeria employers. Such a dispute could have been settled before the notice expires hence strike action of unions could have been averted using (ADR) Alternate Dispute Resolution rather than violence.

Another cause of incessant industrial strikes in Nigeria could be traced to a breach of agreement between the Employees and Employers of Labour. Few examples may suffice here. ASUU (Academic Staff Union of Nigeria Universities went on strike for over six months in year 2009 over a breach of agreement between the Union and the Federal Government of Nigeria; the Obafemi Awolowo University teaching Hospitals' Doctors also went on strike about the same time. Again, ASUU embarked on a week warning strike that commenced on Monday 26 - 30 September 2011 over a breach of agreement reached by the parties (ASUU \& FGN) in 2009 to raise budgetary allocation for education sector to $26 \%$ of the total budget to meet the UNESCO benchmark for all nations. See the Nation Daily Newspaper Saturday September 24, 2011 at p. 2. As at 3rd January 2013, the Nigeria Labour Congress was threatening to embark on industrial strike over a breach of minimum wage contract between NLC and Federal Government.

Unfortunately, these strikes have negative implications on the citizens especially the poor. The rich, that is, the political elite may jet off the country to receive treatment and may send their children abroad to receive education. Regrettably, these opportunities are not available for the poor. Perhaps, this is why the political elite put up lakadaiskal attitude to the Unions' demands and breach agreements with all impunity. In order to minimize these unfortunate happenings in an oil producing country, Nigeria for that matter, hence the objective of this paper is to reexamine industrial relation issues for industrial peace to reign in Nigeria.

The main objective stated also raises some research questions and statement of problem which highlight the following questions: what is industrial strike and what are its causes? What effect has it on level of performance and productivity of workers? Who suffers from industrial strikes, Employer or Employees? How can industrial strikes be averted? How can the disputes be settled amicably without damaging services delivery to the people? These research questions inform the objective of the paper as stated above, as well as research problem. Thus the research problem emphasises the need to close the lacuna of disharmony existing between the Nigerian Employers and Employees which Nigeria Labour Congress stands for. As long as disharmony exists, there might be no industrial peace and this may have a negative effect on the economy and the beneficiaries of the Nigeria Economy. Obviously, there is no conflict free society or organization but how to manage strikes and conflicts is the concern of this paper.

\subsection{A Review of Literature and Theoretical Exposition}

In order to create a gap in knowledge which this paper intends to fill as pointed out earlier on and that is, a harmonious relationship between Nigeria Employers and Employees, an aggressive review of literature was undertaken to bring out areas of agreements disagreement, and contradiction among (if any) scholars who have worked on the related topics to this paper and consequently bringing out a gap in knowledge yet to be filled. Such review includes conceptual review, empirical review and theoretical analysis. Scholars whose works were reviewed include: Ubeku, (1983) Dafe (1995), Sanni (1999), Dunlops (1958), and Bamidele (2005). This review was beefed up with legal review of the Federal Government of Nigeria Trade Disputes Act, the Nigeria Constitution 1999 as amended in 2011 and 
Federal Government, of Nigeria: Workers Compensation Act, 1990.

Aside the empirical review, conceptual review was also attempted for clarification. Such concepts reviewed are (i) Labour, (ii) Management, (iii) Government, (iv) Industrial Strike and (v) Labour Law (vi) dispute and conflict, (vii) Industrial strike and (viii) governance. These concepts cut across this paper. Finally, a theoretical framework was identified upon which this paper was hinged and these are theories of motivation which include Abraham Maslow, theory $\mathrm{X}$ and $\mathrm{Y}$ and Max Weber theory of Bureaucracy. These theories are relevant in the sense that once Employers are able to motivate workers by providing transportation facility, training and retraining, comfortable work environment, attractive wages and salaries, health facilities and promotion as at when due, workers complaints are likely to be minimal hence industrial conflict may be averted and not be frequent as we have it in Nigeria now: Since workers do not operate in a vacuum, hence the theory of bureaucracy is also relevant as workers are governed by bureaucratic rules and regulations as propounded by Max Weber. The hierarchical structure of the bureaucracy, as an institution must be followed, and consequently both the employers and the employees would be able to achieve organizational goal of service delivery to the people. Again, strict compliance of rules and labour law by the two parties (Employers and Employees) will also minimize industrial disputes and strikes especially when workers' representatives are involved in decision making that affect their unions.

\subsection{Conceptual and Empirical Review}

Few conceptual and empirical reviews were undertaken to establish concept and empirical write-ups related to industrial issues. These are analyzed as follow:

i. Statutes: These are legislations made by Parliament. They are deemed to be the Acts of the National Assembly. They also include statutes of general application which were in force on January 1, 1900. The laws that came into effect after this date in England are not part of the Nigerian Laws. Thus:

"Subject to the provisions of this section and except in so far as other provision is made by any federal law, the common law of England and doctrines of equity together with the statutes of general application that were in force in England on the 1st day of January 1900 shall be in force in Lagos and in so far as they relate to any matter within the exclusive legislative competence of the Federal legislature shall be in force elsewhere in the federation. [I]"

ii. Common law/Case laws: Another source of labour laws is the Common Law/Case law which is a body of rules formulated by courts. The rules constitute binding precedent to subsequent cases. We now consider the constitutional provision in respect of labour issues as they relate to human rights.

\section{The 1999 Constitution and Labour Right in Nigeria}

The 1999 Constitution as amended (CFRN) of the Federal Republic of Nigeria is the Supreme law and is the grundnorm hence any law which conflict with it or is inconsistent with its provisions shall be to the extent of the inconsistency null and void. See section 1(3) of 1999 CFRN [2]. See also AG Lagos State V. AG Federation, and AG Abia State V. AG Federation.

Specifically Section 40, CF'RN 1999 guarantees the right of every Nigerian to form or belong to a trade Union or any other Association for the protection of his interest. However, Section 45 of the Constitution permits derogation from this all important right in the interest of defence, public safety. public order, public morality or public health or for the purpose of protecting the right and freedom of other persons [3].

Presumably, the Trade Disputes (Essential Services) Act and the Trade Union Act itself were made pursuant to Section 45. Still on the constitutional provisions for Labour and Industrial relation development, Section 17(3) of CFRN 1999 under Chapter 2 Fundamental Objectives and Directive principles of State Policy relates to labour law. Specifically Section 17(3) deals with labour matters when it states: The state shall direct its policy towards ensuring that:

a) all citizens without discrimination of any group whatsoever, have the opportunity for securing adequate means of livelihood as well as adequate opportunity to secure suitable employment:

b) conditions of work are just, and humane and that there are adequate facilities for leisure and for social, religious and cultural life;

c) the health, safety, and welfare of all persons are safeguarded and not endangered or abused.

d) there are adequate medical and health facilities for all persons;

e) there is equal pay for equal work without discrimination on account of sex or any other ground whatsoever" children. young persons and the aged are protected against any exploitation whatsoever, and against moral and material neglect;

f) provision is made for public assistance in deserving cases; and

g) the evolution and promotion of family life is encouraged.

Regrettably, this section is not justiciable that is, it is not enforceable. See Section 6(6) (e) of 1999 Constitution [3].

\section{What Does Labour Involve?}

One of the essentials of Labour/Management/Government relation is that there must be contract existing among the triad. To start with, a contract is an agreement that is legally 
binding or enforceable usually between the parties. Thus a contract of employment can be defined as an agreement that creates the relationship of employer and employee [4]. In this sense. the Government represented by the management and the employees represent the labour. The relationship contains terms that are legally binding on them. It should be noted that contracts of employment are binding like any other contracts.

\section{Terms of Contract}

In order for a contract of employment to be binding like other contracts generally it must satisfy ingredients of validity. These ingredients are

i offer

ii. acceptance

iii. consideration

iv. intention to enter into a contractual relationship and

v. capacity of the parties to enter into a contract.

All these ingredients must be present or be met for a valid contract to stand and be enforceable7. It should be noted that once any of the elements is missing, the contract is invalid and hence unenforceable.

It is pertinent to briefly examine these legal concepts notwithstanding the facts that we are not in the Law of Contract class, yet their consideration will enable the tripartite institutions (Labour, Government and Management) understand more what the law requires of the parties when they are entering into contract of employment with a view to managing Public Interest and Rights. We now discuss each of the legal terms:

\section{i. Offer}

An offer has been defined as an expression implied by one person or a group of persons, or by agents on their behalf, made to another of his willingness to be bound to a contract with that other person on terms either certain or capable of being certain. The terms of the offer must be lucid and capable of being accepted. It must be communicated to the other party.

\section{ii. Acceptance}

An acceptance is an indication by the person to whom the offer is made to accept unconditionally the terms of the offer and to be bound by them in accepting the offer, The offeror must not vary the term otherwise he or she would be deemed to be making a counter offer and until the person who first made the initial offer accepts the counter offer, there cannot be any valid agreement in existence [3].

\section{iii. Consideration}

The classical definition of consideration is the one put forward in Curie V. Misa (1875) that a valuable consideration in the eyes of law may consist either of some right, interest, profit, or benefit accruing to one party or some forbearance, detriment, loss or responsibility given, suffered or undertaken by the other [3]. The truth of the matter is that, consideration is that which the parties give to each other in order to derive a benefit under the contract. In law, it does not have to be adequate once it is sufficient.

Thus if a man agrees to sell his goat for a tuber of yarn, it would be regarded as a sufficient consideration that could make the contract enforceable against him. Relating the concept, consideration to employment, the consideration from the point of view of an employee is the salary that the employer pays while from the point of view of the employer, the services rendered by the employee/ worker is the consideration.

\section{iv. Intention to Enter into Legal Relations}

Certainly, the intention is that the parties are to be bound by the contract is usually inferred from the consideration [3]. The common law rather fictionally take the view that when trade unions and employers reach collective agreement, they do not intend that it would bind legally and so the courts have held that collective agreements are not, except the terms are reduced into individual's contract of employment.

\section{v. Capacity to Enter into Contractual Relation}

A person cannot enter into a valid contract of employment unless he/she is of sound mind and has reached the age of majority [3). A person who is under the age of 16 years is not capable of entering into contract of employment as a manual or clerical worker except as an apprentice. See Section 9 of the Labour Act. The parent or guardian of a person above the age of 12 years and under 16 years with the consent of the person may by a written contract permit an employer to train the person for a trade or employment in which art or skill is required or as a domestic service The term of apprenticeship in the case cannot exceed five years.

Furthermore, when the young person is up to 16 years and above, he may apprentice himself for the same term. See section 49 of the Labour Act. Note also that the contract of apprenticeship must be duly attested to by a labour officer otherwise, it is void. See Sections 50 and 53(2). It is also an offence punishable with a fine not exceeding N500 or imprisonment for a period of one year or both to remove or to attempt to take out of Nigeria, an apprentice who is under the age of 16 years. See Section 53(1) [5].

\section{Statutory Terms}

The labour Act which is applicable to all clerical, and manual workers makes it mandatory for employers to give their workers not less than three months after the beginning of a worker's employment written statement specifying the following terms.

- The name of employer or group of employers and appropriate undertaking by which the worker is 
employed; the name and address of the worker and place and date of his engagement.

- the nature of his employment.

- if the contract is for a fixed term; the date when the contract expires.

- the appropriate period of notice to be given by the party wishing to terminate the contract which must conform with the provisions of Section 2 of the labour Act.

- the rate of wages and method of calculation thereof and the manner and periodicity of payment of wages.

- the terms and condition relating to:

i. hours of work

ii. holidays and holiday pay.

iii. incapacity for work due to sickness or injury including any provision for sick pay and any special condition of the contract, See Section 7 of the labour Act. The employer has a duty to inform, the worker of any change in the terms not more than one month after the change[7].

\section{Terms Forbidden in Contract}

The following terms cannot be included in contract of employment of manual or clerical workers.

1) That wages shall be paid at intervals exceeding one month unless it is authorized by the State. See Section 9(4) of the Labour Act.

2) That a worker can be made liable for the debt or default of another person. See Section 9(5) of the Act.

3) That a worker's employment shall depend on whether he joins or does not join a trade union or that he shall or shall not remain a member of a trade union. See Section 9(6) of the Act. A worker cannot be dismissed or be prejudiced by reason of trade union membership or because of trade union membership or because of trade union activities outside working hours or within working hours with the consent of the employer [3]. See Section 9(6)(b). Also see ASUU v. University of llorin. (2001)

4) Any provision excluding or limiting the liability of an employer in respect of personal injuries caused to an employees. See Section 12(2) of the Act. Also See Compensation Act 2007 [3].

\section{Public Interest}

By public interest we mean the desires and aspiration of the entire citizenry. This implies availability of comfort of life for the entire members of a given society. Such provision of facilities like, health. education, transportation, food, water, electricity, housing etc. are expected to be readily available on a continuous basis[8]. The only competent institution to provide and manage such key public interest is the government hence this brings us to what is government?
By government, we mean the structures and systems by which decisions and rules are determined and enforced for all members of the society. The Legislature, the Executive and the Judiciary are all parts of the government that is supposed to manage Public Interest analysed above. Each of the arms of government is constitutionally empowered to make and enforce decisions, rules and regulations on all members of the society and their members too. See Sections 4, 5 and 6 of the 1999 Constitution of the Federal Republic of Nigeria (CFRN) [9].

These institutions are different from those of private governing bodies like labour unions, schools, and social clubs and of course the latter are limited in their jurisdictional powers. It is however important to make a distinction between the State and Government. A state is a Community of citizens who are politically organised in a definite territory. It possesses constitutional and legal independence (sovereignty) over all the inhabitants in its area. The major elements of State are a population, a territory, a government that is reasonably independent from external control that is, it possesses sovereignty and thus has power to make binding decisions on all the inhabitants of the state $[101\}$. The government is therefore, the main institution of the state and it functions administratively through its Management Staff who initiate and implement government policies to meet the public interest that is its clientele.

The study of the subject-matter of government deals with wide issues. It extends to the rules and regulations by which a group of people govern themselves, the constitution, the tradition and customary practices upon which those rule are based, the institutions and political structures and organisations set up to implement those rules, the culture and behaviour patterns of the people. It also deals with relationships among states.

Similarly, the resources are available to the agencies of government whether these are internally generated or externally have implication on how the government operates and whether the government will succeed or fail. We now address the issues surrounding the establishment of government.

\section{The Rationale for Setting up Government}

The question is for what purpose does government exist? It would appear that government exists all over the Universe for:

(i) Protection of citizens;

(ii) Promotion of Individual and General Welfare;

(iii) Provision of essential functions; and

(iv) Business Enterprises

The constellation of the above factors constitutes public interest which is another dependent variable in this paper. Let me briefly flesh up these functions. 


\section{a) Protection of Citizens}

This function demands the protection of citizens; rights from invasion from outside and also in maintaining peace and order at home. Internal peace is secured through the efficiency and effectiveness of law enforcement agencies 21 . Furthermore, the liberty of individual and group is protected through the enforcement of the rule of law. All things being equal, the police maintain internal order while army is in charge of external aggression.

\section{b) Promotion of Individual and General Welfares}

It is the duty and responsibility of the State to provide favourable condition under which individuals may and can fulfil their potentialities, such as establishment of schools and agencies through which individuals may realize their abilities [3].

\section{c) Provision of Essential Services}

The state government must perform those functions which are necessary to uphold its integrity, safeguard and legitimize its continued existence. Such duties include the maintenance of incorruptible police for internal peace-keeping, maintenance of courts for punishment of offenders and protecting human rights[3]. Furthermore, government ordinarily, should run certain services for the public interest such as road construction, building schools, taking care of the old, the sick, the orphans and the infirm as well as the unemployed.

\section{d) Business Functions}

Government like individuals may intervene in the economy through the instrumentality of Public Enterprises to provide certain services which are allowed to be provided; and which the poor may not be able to afford the cost, if it is privatised [3] Even though government may have no business in business enterprises but where the public interest is highly necessary such as security, banking, minting of currency and where the project involves heavy capital and finally, to reduce inflation, government may come to protect the public interest.

In some cases government may go into monopoly where competition may be undesirable, and uses its monopoly position for public interest, that is good of all.

Having discussed the labour and labour law, government and management mentioned concepts that need close relationship in order to maintain public interest which depends on the close relationship of the triad (Labour Government and Management) which constitutes an Independent variable that Public interests rest on.

In essence, the harmonious relationship of the triad will go a long way to maintain the Public Interest already analysed. If the triad is in disarray then Public Interest may be in jeopardy.

In a résumé, Government must cooperate with labour and management must also cooperate with labour.

\section{Inevitability of Conflict}

It is an irrebuttable statement of fact that there is no conflict free society hence if and when such conflict arises among the triad there is need for the trio to respect the labour law which is a legal instrument for settlement of disputes already discussed in this paper. It is obvious that nobody is above the law with few exceptions-(Immunity clause) see Section 308 of the 1999. CFRN [3]. We now briefly look into employment condition of women and young.

\section{Regulation of Employment of Women and Young Persons as Manual or Clerical Workers by the Labour Act}

Generally, a woman cannot be employed on night work. This provision does not apply to nurses or persons in agricultural undertaking who engaged in manual labour. Night work for women is permissible where the night work is due to unforeseeable interruption of work and is not recurring or it has to do with raw materials which are likely to get spoilt fast.

No woman can be employed in an underground work in any mine unless she is undergoing a study which requires such work or she occasionally enters the underground parts of a mine for a non-manual work. See Section 56 of the Act. A women entitled to be absent from her work six weeks before her confinement is due and six weeks thereafter, if she produces a medical certificate to that effect [5].

In such cases, she is entitled to her full salary and 16 weeks off duty in the University but in the Civil Service, the law says she is entitled to $50 \%$ of her wages regardless of her absence and cannot be given notice of dismissal during her absence. In like manner, a woman must be allowed half an hour twice a day to nurse her baby during working hours.

Generally, no young person shall be employed during the night. But young person over the age of 16 years may be employed at night:

- $\quad$ in the manufacturing of iron and steel.

- glasswork.

- manufacturing of paper, raw sugar and

- gold mining reduction work. See Section 60 of the Labour Act. [3]

A young person under the age of 15 years cannot be employed in a vessel (ship) except the vessel is a school or training vessel or only member of his family are employed in the vessel. See Section 61 of the Labour Act. No young person under the age of 16 years can be employed to work underground on machine work or on public holiday. See Section 59 of the Act.

No child can be employed except by members of his family to work on light work of an agricultural, horticultural or domestic character approved by the Minister. A child 
cannot be employed to lift, carry, or move anything so heavy as to likely injure his physical development. See Section 59 of the Act. A young person under the age of 14 years can only be employed on a daily wage and day-to-day basis provided he or she returns each night to the place of residence of his/her parents or guardians. See Section 59 of the Act and finally, every employer of young persons must keep a register of all the young persons in his industrial undertaking with particulars of their age, date of employment and nature of their employment. See Section 59 of the Act.

\section{The Public Officers and Termination of Employment}

In Nigerian law, the word 'worker' is often used interchangeably with employee. For example, Section 47 of the Trade Disputes Act defines a worker as any public officer or any individual (other than a public officer) who has entered into or works under a contract with an employer whether the contract is for manual labour, clerical work or otherwise, express or implied, oral or in written or whether it is a contract of service or of an apprenticeship. See also Section 52 of the Trade Unions Act. However, worker does not include any person exercising administrative/executive or technical functions under Section 91(1) of the Labour Act.

\subsection{Public Servants/Officers}

A public officer is any person employed in the service of either the Federation, or of a State in any capacity. See Section 318 of the CFRN 1999. By virtue of Section 318 of the 1999 Constitution, public servants would include staff of the following establishments:

National Assembly, the judiciary, or authority established for the Federation, or for any stale, area council, local government council, statutory corporation, company or enterprise in which government has controlling shares or interest, educational institutions established or financed principally by the Federal Government or of any State. [3]

\subsection{Common Law Employees and Termination of Employment}

Workers who are employed in the private sector or even in government establishment but whose terms of employment are governed or regulated by contract alone and not by statute are common law employees. The relationship is described as one of master-servant.

The employment of Common Law workers can be terminated by either the worker or the employer upon notice or upon payment of salary in lieu of notice. The length of notice is as contained in the contract of employment[1 I].

Regrettably the dominant view in legal jurisprudence is that an employer can terminate the employment of a common law employee for good or bad reason or for no reason at all, once the employer has given the required or reasonable notice as the case may be. So long as he acts within the terms of employment, his motive for doing so is irrelevant. The courts have also repeatedly held that the only remedy an aggrieved employee has, lies in damages calculated on the basis of what he would have earned for the period of notice agreed for ending the employment. See Idomiboye Obu V. NNPC 2002, 2 NWLR (Pt). 305, 589 at $526-627$.

Ostensibly, the rationale as stated by court is that, the court will not force or impose a willing employee on an unwilling employer. Some have also argued that the employee could also leave the employer upon a reasonable notice. The court assertion can also be inferred from legal principle of fundamental human right and imply it means that you have the free will to associate with any organisation with no compulsion. The legal jurisprudence also asserts that as long as there is a formal contract of relationship between employer and employee, either party can withdraw provided that legal obligations as stated in the contractual document such as appointment letters, oath of office etc. It also follows that before a public officers appointment could be terminated, due process in line with constitution. Alas some of these laws are not always respected especially during the military administration where the State Governors could just wake up and decree that the officer should be dismissed with or without due process. Similar behaviour was on record when civil servants were sacked at Federal and State Government levels. In some of these cases the legal maxims of (Audi Alteram partem and Nemo Index. In cursor sua) were jettisoned, meaning that the authority may not necessarily listen to the other party and the Employer cannot be a judge in his own course. In brevity any of the parties can check out of the contract as long as due process is followed.

The rationale as stated by the court is that the court will not force or impose a willing employee on an unwilling employer Some have also argued that the employee could also leave the employer upon a reasonable notice[12].

\section{Employment with Statutory Flavour}

Employments that are governed by statutes which regulate mode of employments, rights, privileges and duties of the employees and how the employment can be determined or terminated are said to enjoy statutory flavour. Failure to comply strictly with the statute renders the dismissal of the employee null and void. In such case, the court will readily order reinstatement of the dismissed or sacked employee31. In such a situation, the employee must be able to show that there is a statute that protects his or her employment. In other words, an employment is said to have statutory flavour if the employment is directly governed or regulated by a statute or a Section of the statute that delegates power to an authority or body to make the regulations or conditions of service as the case may be. See ldomiboye-Obi V NNPC (2003) 17 NWLR (Pt 795) p. 139 at p. 147. See also ASUU V. 
University of Ilorin (2001). In the case of employment protected by statute, the fact that the employee is dismissed or retired without complying with the procedure prescribed by the statute and accepts benefits does not validate the determination which is void ability[13].

\section{Trade Unions, the Law and Industrial Disputes}

We have seen that the bedrock of modern labour/industrial relation development is the right the worker and his employer have to come to agreement on the terms and condition of employee's employment. With the emergence of trade Union, this relationship is regulated more and more through collective bargaining between the employer and the Union on behalf of their members.

Disagreements often occur in the workplace between the workers and the management on the one hand and among the workers themselves on the other hand. In the trade union, there are also cases of disagreements on internal management and running of the affairs of the union. Disputes sometime exist between two or more trade unions on jurisdiction to organize workers in a particular trade or industry[14]. This is what is referred to in popular parlance as poaching".

Unless these disputes are resolved promptly, industrial peace maybe disturbed with the negative effect on productivity. We now briefly examine industrial conflict.

\section{Industrial Conflict}

In spite of all the elaborate statutory provisions: Trade Disputes Act, Trade Union Act and Workmen's Compensation Act CAP 470 etc, made for ensuring peace in industry (private and public) hardly any week passes now without strike action or a threat of it in one form or the other in Nigeria. The mounting state of near anarchy in both public and private sector of industry does not seem to justify the hopes of legal draftsmen. For instances, ASUU (Academic Staff Union of Universities) went on strike for over six months in year 2009 over breach of contract between the Union and the Federal. Government; the Obaferni Awolowo University Teaching Hospital doctors went on strike just a few months ago and the Osun State Medical doctors took over the strike. In Oyo State, the doctors are currently on strike while Lagos State doctors were down tooling a couple of weeks ago just to mention a few. The Osun State Government workers just resumed last week Monday after about 5 weeks' strike. And yet the medical doctors, Nurses and other health workers are still at home34. The ASUU (Academic Staff Union of Universities) freshly embarked on a week warning strike commencing on Monday 26th September to 30 September 2011 over a breach of agreement reached by the parties that, is ASUU and The Federal Government of Nigeria in 2009 to raise budgetary allocation for education sector to $26 \%$ of the total budget to meet the UNESCO benchmark for all nations. See the Nation Daily Newspapers, Saturday September 24. 2011 at p. 2. As at 3rd January 2013 NLC was threatening to embark on industrial strike over breach of minimum wage contract[14].

Yet there is nothing in any law, not even in the sacrosanct Trade Disputes Act 1976 that affects the right of any person to choose who he is to serve, and when he may decide to quit his job[17]. In Nigerian law, the different categories of disputes have been given different terminologies. Disputes between workers and the management or among workers which is connected with employment or non- employment, or the terms of employment and physical condition of work of any person known as trade disputes. See Section 47 of the Trade Disputes Act CAP 432 1990. Disputes within a trade union on internal governance of the union are called intra union disputes, while disputes between two or more unions are referred to as inter-union disputes[3].

It should be noted that the courts have given judicial support to the legislative definition of trade dispute contained in Section 47 of the Trade Disputes Act. The section defines a trade dispute "as any dispute between employers and workers or between workers and workers, which is connected with the employment or non-employment, or the terms of employment and physical condition of work of any person ". [3]

The following elements must be present before a dispute can qualify as a trade dispute

a) The dispute must be between employer and workers.

b) The dispute must be connected with the employment or non- employment of any person or

c) The dispute must be connected with the terms of employment or physical condition of work.

The last two conditions are disjunctive. Once the first element and any of the two other elements are present, the dispute is a trade dispute. In the words of Aturu39. the Court of Appeal erred in the case of NURTW v. Ogbodo when it added another element, namely, that the dispute must involve a trade. That element is not contained in the definition of trade dispute in the Act.

\subsection{Intra-union Disputes}

Intra-union disputes are those arising from the Organisation and running of a trade union as laid down in the Union Constitution- See Section 24 of Trade Union Act. CAP 432 (1990). Such matters as to the propriety or otherwise of political or other affiliation and complaints arising from election into union offices will certainly come within this sub-head of disputes 40 .

\subsection{Inter-union Disputes}

There are disputes arising from the restructuring of trade unions. Disputes on proper union that can unionize certain categories of workers are included in this class of disputes. As the name suggests, the dispute is usually between two or more trade unions. Original jurisdiction to hear and 
determine matters arising from inter-union disputes originating from the restructuring of trade unions is conferred on Industrial Arbitration Panel.

\subsection{Point of Controversy}

It is a clear statement of fact that there is no conflict free organisation and so there is always a dispute between the labour and the management. It is also a fundamental rule of labour law that a worker who gives a prior notice is entitled to withdraw his labour. Even the provision of Trade Disputes Act restricting or banning strikes and lockouts has not affected the common law right of the citizen to quit his job[3]. The point of controversy has been the position as to strike, that is, when, workers may collectively or temporarily withdraw their labour or indicate their intention to do so. Judicial and academic opinions are diverse and conflicting, as. Lord Wright stated:

When the rights of labour are concerned the rights of the employer are conditioned by the rights of the men to give or withhold their services. The right of the workman to strike is an essential element in the principle of collective bargaining.

Writing on the judgment of the Court of Appeal in Rookes V. Barnnard, Professor Wedder Burn sees the decision as vigorous reaffirmation of the right to strike. The "policy" of the judgment may be said to be that the struggles between courts and the union bequeathed to modem English industrial law, namely, the recognition of the right to strike for collective union interest.

And in his review of the Industrial Relations Act in its bill form, Ken Foster canvassed the view that "one of the basic underlying principles of the bill is that an employee is free to withdraw his labour, subject only to the requirement of his individual contract of employment. It is therefore, vital for him to know when strike action will be a breach of his contract 43 .

In view of these judicial and academic pronouncements, it seems now to have been conceded that there are circumstances when a strike notice will be legitimate and recognizable in law44. Foster is of the view that the contractual legality of a strike will depend upon the effect of the notice given. 'The strike will be lawful only if the notice operates as notice of termination or suspension, otherwise it will not.

It is clear that notices to terminate a contract are lawful. Professor Grunfeld has been quoted as saying that the decision of the English Court in Sporing Head Spinning Co. V. Riley was the earliest authority in support of the proposition that "termination of legal employment relationship by due notice has been the common Law basis of the right to strike since 1868 [20].

Furthermore, Lord. Justice Russell said in Morgan V. Fry that if the workers had determined the employment by the seven days' notice required under the law there would have been no breach of the contract. And Lord Denning observed that, "the, men can leave their employment altogether by giving a week's notice to terminate it" [18]. But the question is: when is a strike or a notice of it is a breach of employment?

Certainly, the workers will be committing a breach of their contract if they simply walk out of their job without any notice whatsoever. This often occurs when workers take spontaneous action in respect of any conduct by the employer which the" consider inimical to their collective interests.

Such was the situation in Rookes V. Barnard and Daily Mirror Newspapers V. Gardner. In the latter case, Lord Dennings illustrated the point with the example of a working man who has a contract to serve at a week's notice. Such a person cannot say "I am going to stay away one day" just to please himself. If he does stay away for one day, he is guilty of a bro contract. We now shift to analysis of mechanisms and procedure for Dispute Resolution.

\section{Mechanism and Procedure for Dispute Resolution}

As long as there is a dispute in industrial and Labour relations; there is also a legal mechanism put in place to resolve it. There are:

\section{(a) Mediation: (Section 3(2) and 5)}

In case the parties are unable to reach a settlement under the agreed procedure or if no such agreement exists, both sides must meet within seven days under a mediator appointed by the parties with a view to settling the disputes amicably. See Section 3(2) of the Trade Dispute Act. If the parties within seven days are still unable to arrive at a solution, they have a duty to inform the Minister formally, in their report to the Minister, they are required to state the points of disagreement and dispute (Section 5) [17].

By virtue of Section 6, the Minister may, if he is not satisfied that the provisions on mediation (Section 3) have been complied with and after 14 days of issuing a notice giving directions which have failed to resolve the dispute, exercise his discretion to appoint a conciliator or refer the dispute for settlement to the Industrial Arbitration Panel (IAP) within 14 days of receiving the report of the failure to reach a settlement under the mediator or within 7 days of receiving the report of the mediator, refer the dispute to the National Industrial Court if the workers involved in the dispute are employed in essential services or if it is inappropriate to refer the dispute to the lAP. The Minister may constitute a board of inquiry to look into the dispute[3].

\section{(b) Conciliation: (Section 7 of the Act)}

The task of a conciliator appointed under Section 7 of the Act is to negotiate with the parties in disputes with a view to bringing about a settlement. If the conciliator reaches a settlement within 7 days of the appointment, he is under obligation to send the terms of settlement signed by the 
parties to the Minister. The terms are binding on the Workers and the Employers to whom they relate. Any act in breach of the terms of settlement is an offence punishable in the case of a worker or the worker's union with a fine of N200 but in the case of an employer or employer's union with a fine of $\mathrm{N} 2000$. Where the conciliator is unable to resolve the dispute, he also has a duty to report the fact to the Minister. (Section 7) [3]

\section{(c) Arbitration (Sections 8 \& 12)}

The Minister may decide, upon failure of mediation within 14 days of receiving the report thereof, refer the dispute to the Industrial Arbitration Panel (Section 8). An arbitration tribunal of one or more arbitrators constituted by the chairman of the I.A.P listens to the parties or their representatives on the dispute[3j. The Act also permits the union to make their input in nominating equal number of arbitrators for the Panel in deserving cases.

The Arbitration tribunal must make its award within 21 days, except the Minister grants an extension of time. The award must not be communicated to the parties involved but directly to the Minister. The Minister may decide to refer the award to the tribunal for reconsideration or give it to the parties and publish it in a notice (Section 12(4)) or Federal Gazette and, the award shall be binding on the employers and workers to whom it relates as from the date of the award[3].

\section{(d) National Industrial Court (Section 1 6)}

Should any of the patties file an objection to the award of the lAP within seven days and in the manner stipulated by the Minister, the Minister shall refer the dispute to the National Industrial Court[2 1]. The award of NIC shall be final and binding on the workers and employers from the date of the award. The amendment to the Act permits appeal to the Court of Appeal from the decision of the NIC only on questions of fundamental rights.

As noted earlier, the Minister is permitted to side step arbitration and conciliation and refers a trade dispute directly to the NIC where the workers concerned are engaged in essential service or it is inappropriate to go to arbitration (Section 16). Be that as it may, we now examine another legal frame work that can enhance industrial and labour development and that is, work men's compensation, Act CAP 470, LFN 1990[3].

\section{The Workmen Compensation Act Cap 470 LFN 1990}

The Act makes provisions for the payment of compensation to workmen for injuries suffered in the course of their employment. Section 2(1) of the Act states that.

Subject to the provisions of this section, this Act shall apply to a workman employed:

(a) in the public service of the Federation or any State thereof; and (b) in the Nigeria police force in the same way and to the same extent as if the employer were a private person.

Specifically Section 3(1) affirmed that subject to subsection 2 of this section, if in an employment, personal injury by accident arising out of and in the course of the employment is caused to a workman, his employer shall, subject as hereafter mentioned, be liable to pay compensation in accordance with the provisions of this Act[3]. The Act further stated in Section 4(a) where death results from the injury and

a) the workman leaves any dependant wholly dependant on his earning, the amount of compensation shall be equal to forty-two months earnings, but where in respect of the same accident compensation has been paid under the provisions of Sections 5, 7 or 9 of this Act, there shall be deducted from the sum payable under this paragraph any sums so paid as compensation.

b) the workman does not leave any dependant wholly dependant on his earnings but leaves any dependant in part so dependant, the amount of compensation shall be such sum, in any case not exceeding the amount payable under paragraph (a) of this section as may be determined by the court to be reasonable and proportionate to the injury to the said dependant.

c) the workman leaves no dependant, reasonable expenses commensurate with the last position held in his employment by the deceased shall be paid by the employer.

Finally, Section 5 of the Act says: where permanent total incapacity results from the injury, the amount of compensation shall be a sum equal to fifty four months earnings and Section 6 states that where an injury results in permanent total incapacity of such a nature that the injured workman must have the constant help of another person, additional compensation shall be paid amounting to one-quarter of the amount which is otherwise payable under Section 5 of this Act[3].

In sum, the rationale for the workman compensation Act is to enhance labour and industrial development in Nigeria. It also guarantees harmonious employees/employers relationship.

We now turn to bargaining process especially the voluntary process all to enhance labour/industrial development.

\section{Path to Industrial Harmony}

Having discussed the nature and objects of a trade union and the legal framework guiding industrial relations, we will briefly discuss the procedure the union adopts to fulfill its main object of promoting the welfare of its members. In essence, we will discuss bargaining process from union perspective. We had earlier on discussed the powers, functions and the role of Minister of Labour in enhancing 
peaceful harmony and industrial relations in Nigeria. To achieve its objective, a trade union should therefore strive as much as possible to make use of available negotiating machinery for achieving maximum benefits for all its members with minimal friction. To achieve its main objective, a trade union need not be unduly bellicose, it would augur well for better industrial harmony if its mission could be fulfilled without conflict. Unfortunately, this is not always so in practice; for there are instances when unions have misused their collective strength..

Basically, in order to avoid frequent conflicts, a few orthodox procedures have been evolved in industrial negotiations. Some of these are products of business practice while others are laid down by law. Statutes have for instance, provided some machinery whereby leaders of a trade union organization can sit down with the management round a negotiating table and iron out their differences in an atmosphere of mutual trust and understanding. e.g. ASUU and the Federal Government. This is termed "Collective Bargaining" a term which has been defined [22] as "negotiation with respect to terms and conditions of employment, or with respect to making variation or recession of a procedure agreement, or with respect to any matter to which a procedure agreement can relate"

\subsection{Voluntary Method}

The general principle of industrial relations recognises the right of both employer and workers to negotiate the terms of their agreement57. However, the emergence of trade unions has led to a situation whereby the position can now be regulated more or less by collective bargaining between the workers union and the employers once the initial contract of employment has been concluded.

It should be noted that, there are no statutory provisions which regulate the collective bargaining process and ensure the observance of agreement reached by the negotiating parties. The law has, as it were scrupulously abstained, primarily because it has been the policy of the government since 1938 when the first Trade Union Ordinance was enacted[1 I].

\subsection{Conciliation and Arbitration}

The Trades Dispute Act 1976 (now CAP 432 1990) gives the Minister of labour power to intervene in industrial dispute, existing or apprehended, with the object of promoting settlement by reconciliation[ 17]. Under the Act, the parties are required to meet first on their own or under a mediator failing which the minister may appoint a conciliator to inquire into the causes and circumstances of the dispute and take whatever steps he might wish to ensure harmonious settlement of the dispute.

\section{Statutory Compulsion and Obligation to Negotiate}

Section 3 of the Trade Dispute Act CAP 432, LFN 1990 makes it obligatory for parties to a dispute to meet within seven days of the existence of a trade dispute and negotiate a settlement either by themselves or under mediators. [3]. The Act goes further that, where the parties are unable to reach an agreement, any of the parties intending to press the matter further is required to declare a trade dispute and notify the Minister within fourteen days of the failure to resolve the dispute by negotiation.

At that stage, three courses of action are open to the Minister. First, he may appoint a conciliator along the line provided by Section 6(1) of the Trade Dispute Act 1976 with the sole object of bringing about an amicable settlement (3). The second option open top him is to refer the dispute to a board of inquiry which is required to report to the Minister. Examples of such a reference are the cases of the Lagos State doctors against the government of Lagos State and association of Consultants of Lagos University Teaching Hospital against the University of Lagos under the 1969 Decree

Thirdly, the Minister may refer the dispute to the Industrial Arbitration panel, which must appoint an arbitration tribunal to try and find a way out of the stalemate. It must be noted that the award of the arbitration tribunal is required to be released within forty-two days of its appointment and is binding on the parties after the award has been confirmed in an Order made by the Minister of labour.

However, the inability to force any of the parties to come to terms with the opponents or compel obedience to the adjudication of an independent peace-maker had apparently created a yawning gap in the process of industrial relations in Nigeria. It seems something had to be done, at least to ensure that the freedom to bargain was exercised within the law. Hence legislation again has to be employed as a means of bringing about a change of attitude to industrial negotiation. The first of such enactment which made the far reaching incursions into the voluntary nature of Nigeria Industrial Practice was the Trade Dispute Emergency, Provision Decree 1968, and Part I of which laid down the procedure for the settlement of trade disputes. Anyway the Decree had been replaced by the Trade Disputes Act 1976 now Trade Dispute Act CAP 432 LFN 1990(3).

\section{The Research Methods}

As this is an empirical study, primary and secondary sources of data were employed to elicit information from the Unions in Obafemi Awolowo University, Ile-Ife. The scope of investigation covered the randomly selected three Unions out of five Unions in the campus. The randomly selected ones are:

(i) ASUU - Academic Staff of Nigeria Universities

(ii) SANU - Senior Staff of Nigeria Universities and

(iii) NASU - Non Academic Staff Union.

The interview method was heavily utilized to obtain facts from the respondents who were purposively selected for interview. They are the Presidents and Vice presidents of the 
Unions representing the Employees while the Registrar and Bursar of the University who represent the Employer (University Senate) were also interviewed. These interviews were beefed up with secondary data which consisted of

(i) University records of industrial strikes

(ii) Union records of industrial disputes and

(iii) Journals, University Magazines, Newspapers Internet sources and legal documents.

The information gathered were descriptively analysed with simple statistical references such as percentages. The findings revealed that, the relationship of workers and their employers is not cordial as all the Unions Presidents interviewed agreed. However, the Registrar and the Bursar disagreed arguing that the demands of labour is always on the high side and excessive which management often rejects. Thus, this opens way for conflict and consequently strike ensues. Furthermore, the result of analysis confirmed that workers' salaries were short paid compared to other Federal Universities but the management denied this opinion. The workers interviewed randomly illustrated causes of disharmony by referring to some states in Nigeria, who are still owing their workers between 3 to 6 months and yet half of the workers entitlement is being paid. The respondents emphasised that there cannot be harmonious industrial relations in such a circumstance as the Governors breach the contractual relation between the workers and the Government (Employer.)

Finally, the Unions/Workers interviewed alleged their Employers (Federal/State Governments) of misplaced priorities instead of addressing the welfare status of workers, the employers engage in white elephants projects. They asserted that this attitude must change if the employers are serious in establishing and sustaining good and friendly relation. In the end, the paper, concluded that there is need for symbiotic relation between employers and employees as labour needs capital and employer needs labour to achieve organisational goals.

In brevity, capital needs labour and labour needs capital simply. Perhaps this adage justifies the symbiotic relations Iwhich must exist between the employers and employees, hence Employers should not view or perceive labour/employees as slaves but as a partner in the same trade.

\section{Summary of the Review of Literature}

These authors (Dafe (1988), Uviegbara (2001), Dunlop (1958), Bamidele (2005), Ubeku (1983), Mc Carthy (1972) etc. whose works were related intimately to Industrial Relations Issues, generally established that every industrial relation system involves three groups of actors: (1) Workers and their organisations, Managers and their organisations, and (3) governmental agencies concerned with the work place and the community. In essence, management of industrial relations for public right and interest is a function of the three groups mentioned above. In short, effective and receptive industrial relations can be determined by cooperation of the three groups.

Furthermore, every industrial-relation system creates a set of rules and regulations to govern the work place and its environments. This assertion informed our review of few rules, statutes and constitution of the Federal republic of Nigeria governing industrial-relation system in Nigeria. These rules may be in form of agreements, statutes, decrees, regulations, policies, practices, norms and customs. The rules, determine the status of employers, and employees and also govern the conduct of all the actors at the work place and the environments (external and internal). The environments in this context consist of three interrelated contexts: the technology, the market or budgetary constraints and the power relations and status of the actors.

In a resume, the constellation of the factors highlighted in the review under conceptual, empirical and theoretical analysis will go a long way to enhance industrial-relation system for managing public right and interest in Nigeria and elsewhere too; if well adopted strict.

What we have attempted in this presentation, (paper) is to grope into legal framework charting the course of Labour and Industrial relations development in Nigeria. To this end, we examined the nature of employment before the advent of the colonialists where employment was casual and communal in nature. Labour service then was not highly monetised as it is today, but it was colonial era that brought industrial employment of labour and consequently a relationship was created between the employers and the employees. One of The implication of this relationship is conflict which needs to be regulated in order to enhance labour/industrial development for managing public interest and right.

In view of the conflict arising from the new relationship, there is need for regulation of such conflict hence the role of law. Thus we briefly discussed the concept of law especially the sources of Labour Law, the Constitution and Statutes as they are related to labour and industrial development. Such statutes include the Trade Union Act 1976, Trade Dispute Act CAP 432. LFN 199063 and Workmen's Compensation Act CAP 470 LFN 199064.

A brief analysis of law of contract was also addressed as an important legal Framework/ analysis where industrial and labour relations originate and rest. The paper also highlighted the regulations and law guiding the employment of women and youth. Finally, we discussed the Trade Unions, Industrial disputes and legal framework for dispute resolution. These include mediation, conciliation, arbitration, industrial court and Court of Appeal.

This legal framework is aimed at ensuring that there is harmony in industry (private and public). It also guarantees labour and industrial relations development in Nigeria. However, it is the opinion of these scholars that in spite of the legal framework put in place, yet Nigerian economy experiences industrial disharmony arising from breach of 
agreements reached by the parties especially the government of federation and the States. It appears that Nigerian governments do not always honour trade unions 14 days ultimatum given to the employers. The ultimatum wills lapse, yet the governments put - up negative attitude and the employees have no alternative except recourse to strike action to wake up the governments from their slumber.

Most of the industrial unrests in the Nigeria economy could have been averted if law is respected by the governments of Nigeria. Again, most of the causes of industrial strikes are created by the governments of Nigeria through under funding of the industry, poor motivation of workers and little respect for trade unions in Nigeria.

\section{Conclusion and Recommendation}

We therefore conclude with the following measures to enhance labour industrial relations development in Nigeria:

1. It is not enough to enact law but the most important thing is to enforce the law in good faith by the law enforcement agency and also to ensure that the citizens must comply with the law as non-compliance or breach of law is actionable and such a breach is punishable if found guilty. After all, it is irrebuttable that "No body is above the law" with limited exceptions. It is however amazing that most of the industrial strikes happening in Nigeria could be as a result of non-compliance with the labour law duly signed by the parties. Nigerian governments are in most cases reluctant to implement labour agreement duly signed with a delay. An example is Academic Staff Union of the Nigeria Universities and the Federal Government, 2009 agreement,. This type of political culture is against labour law and can initiate industrial conflict which ordinarily should have been averted if laws are respected. This attitude must stop if industrial relation is to be enhanced in Nigeria.

2. Furthermore, corollary to suggestion I above is the conception and perception of the employers of labour in Nigeria who see labour/workers/employees as mere instruments of achieving organisational goals, and as servants instead of regarding labour and capital relationship as symbiotic or at worse as partners in the same trade and NOT as Master/Servant relationship as it is now. Without labour input, the organisation is just a mere skeleton because it is the human resources that can be regarded as physiological flesh which makes the organisation functional.

3. The third suggestion is that labour needs capital and capital needs labour. This is a trite statement of fact, a reality which Nigeria employers must understand and uphold. In the absence of labour, capital may not be able to cope as capital provided by the employers cannot drive itself. It is the labour, entrepreneurship and other skills that will plan, and execute the capital resources. To this end, human resources (human capital) is a Sine qua non in organizational management. In the same vein, without capital supplied by the employer, the organisation may not exist as the capital is used to employ labour and to maintain same. All other factors of production, land, labour, entrepreneurship and material depend on availability of capital provided by the employers. It is rather impossible that while other factors of production rest on capital, the capital cannot utilise itself in the absence of labour/human resources. Hence we conclude that the labour as well as capital should be seen as partners in the same trade and are symbiotic.

4. The fourth and fifth suggestions imply that there is need for the employers to adequately fund the industry and motivate the workers therein so that there will be peace, harmony and cooperation between the workers and the employers. If adequate facilities are not on ground, the workers' skill will not be maximized and the purpose of investment of capital will not be achieved. In addition to the provision of facilities, the welfare of workers is also paramount in order to enhance their level of productivity. This motivation includes, good salary, perquisites, good housing, transportation, health facilities and compensation for hazard at work. The constellation of the above packages will enhance good industrial relation between the Employers and the Employees hence a conductive business environment is created in Nigeria.

If all the suggestions are sincerely and honestly addressed, the employees will be ready to put in their best, hence there may be an increase in the level of productivity and excellent performance in both the public and private sectors of the economy and consequently the two parties (Employers and Employees) will gain and enjoy industrial labour relations development. In a resume, the Nigerian politicians should note with all seriousness that the will of the people (electorate), not force is the basis of the State Administration The overall end product of this paper is to ensure that public interest and rights of citizens are safe guarded in Nigeria

\section{REFERENCES}

[1] Ubeku, A. K. (1983). Industrial Relations in Developing Countries. London: Macmillian Press

[2] Constitutional of the Federal Republic of Nigeria (1999) as amended 2011

[3] Ibid.

[4] Unieghara, E. E. (2007). Labour Law in Nigeria. Lagos. Malthouse Press Limited.

[5] Dunlops, J. T. (1958). Industrial Relations Systems. New York: Henry Holt and Company, Constitutional of the Federal Republic of Nigeria, Op. Cit. (1999)

[6] McCarthy, W. E. J. (1972). Unions. England: Penguin Books Limited.

[7] Uyieghara, Op. Cit., (2007). 
[8] Ubeku, Op. Cit., (1983).

[9] Constitution of the Federal Republic of Nigeria, Op. Cit. (1999).

[10] Sanni, A. O. (1999). Introduction to Nigerian Legal Method. Ile-Ife: OAU Press.

[11] Sanni, Op. Cit., (1999).

[12] Federal Government of Nigeria: Workers' Compensation Act CAP 470 (1990).

[13] Uyieghara, Op. Cit., (2007).

[14] Bamidele, A. (2005). Nigeria Labour Law. Lagos: Frankad Publishers Nations Daily Newspaper, 2011, p 2.

[15] Federal Government of Nigeria: Trade Disputes Act CAP 432 (1990).

[16] Dafe, O. (1995). The Trade Union Movement in Nigeria.
Lagos: Malthouse Press Limited.

[17] Federal Government of Nigeria: Trade Disputes Act CAP 432, Op. Cit. (1990).

[18] Dunlops, Op. Cit. (1958).

[19] Foster "Strikes and Employment Contracts" (1971) MLR 274.

[20] Dafe, Op. Cit. (1995).

[21] Federal Government of Nigeria: Workers' Compensation Act CAP 470, Op. Cit. (1990).

[22] Section 167 of the English Industrial Relations Act (1971).

[23] Bamidele, Op. Cit., (2005).

[24] Dafe, O. (1988) "State and Industrial relations in Nigeria" Lagos, Malthouse Press Limited,

[25] The Nation News Paper, Saturday September 24, 2011 at page 2 . 